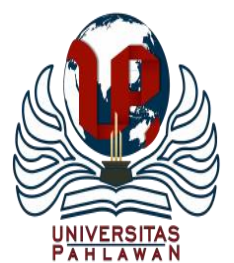

Edukatif : Jurnal Ilmu Pendidikan Volume 3 Nomor 6 Tahun 2021 Halm 3721 - 3727

EDUKATIF: JURNAL ILMU PENDIDIKAN

Research \& Learning in Education

https://edukatif.org/index.php/edukatif/index

\title{
Analisis Implementasi Prinsip Empowerment Pada Kepemimpinan Kepala Sekolah
}

\author{
Marinu Waruwu ${ }^{凶}$ \\ Universitas Kristen Satya Wacana, Indonesia \\ E-mail : marinu.waruwu@uksw.edu
}

\begin{abstract}
Abstrak
Penelitian ini bertujuan untuk menganalisis implementasi prinsip empowerment pada kepemimpinan kepala sekolah. Data dikumpulkan melalui pendekatan mixed method. Penggunaan metode kuantitatif dilengkapi dengan metode kualitatif. Data kuantitatif dilakukan melalui penyebaran kuesioner. Data kualitatif diperoleh melalui wawancara, observasi dan interview sebagai pelengkap data kuantitatif. Analisa data dilakukan dengan explanatory mixed method analysis. Data kuantitatif sederhana dianalisa secara deskriptif dan dilanjutkan eksplanasi dan elaborasi. Hasil penelitian menunjukkan bahwa 1) kemampuan kepala sekolah dalam memberdayakan guru melalui program pelatihan, mendorong rasa tanggung jawab, observasi supervisi rekan sejawat, dan delegasi tugas mendapatkan tingkat penilaian dengan kategori sangat baik; 2) kemampuan kepala sekolah memberikan penghargaan berupa pujian, dorongan, dan umpan balik mendapatkan penilaian dengan kategori cukup. Secara keseluruhan Implementasi prinsip empowerment kepala sekolah pada sekolah dasar mendapatkan tingkat penilaian dengan kategori baik.
\end{abstract}

Kata Kunci: Analisis: Implementasi; Pemberdayaan; Penilaian

\begin{abstract}
The objective of this study is to analyze the implementation of the principle of empowerment in the leadership of school principals. Data was collected through a mixed-method approach. The use of quantitative methods was complemented by qualitative methods. Quantitative data was conducted through the distribution of questionnaires. Qualitative data obtained through interviews and observations as a complement to quantitative data. Data analysis was carried out using explanatory mixed-method analysis. Simple quantitative data were analyzed descriptively and continued with explanation and elaboration. The results show that 1) the ability of the principal in empowering teachers through training programs, encouraging a sense of responsibility, observing peer supervision, and task delegation receive an assessment level with a very good category; 2) the ability of the principal to give awards in the form of praise, encouragement, and feedback to get an assessment with a sufficient category. Overall, the application of the principle of principal empowerment in elementary schools gets an assessment level with a good category.
\end{abstract}

Keywords: Analysis; Implementation; Empowerment; Evaluation

Copyright (c) 2021 Marinu Waruwu

$\triangle$ Corresponding author:

Email : marinu.waruwu@ gmail.com

DOI : https://doi.org/10.31004/edukatif.v3i6.1232

ISSN 2656-8063 (Media Cetak)

ISSN 2656-8071 (Media Online)

Edukatif : Jurnal Ilmu Pendidikan Vol 3 No 6 Tahun 2021 p-ISSN 2656-8063 e-ISSN 2656-8071 


\section{PENDAHULUAN}

Peningkatan mutu pendidikan merupakan tuntutan utama di jaman sekarang ini. Salah satu yang mempengaruhi mutu pendidikan adalah kualitas guru. Pengembangan kualitas guru menjadi salah satu strategi meningkatkan mutu pendidikan. Beragam strategi pengembangan kualitas guru. Menurut Ramaliya, strategi pengembangan kualitas guru antara lain peningkatan kualifikasi pendidikan guru, penyetaraan dan sertifikasi, program pelatihan, supervisi, Musyawarah Guru Mata Pelajaran, simposium, magang, dan penelitian (Ramaliya, 2018). Beragam strategi pengembangan kualitas guru seharusnya berdampak pada peningkatan kualitas pembelajaran apabila pengembangan dilakukan secara terencana dan pengawasan berkelanjutan.

Salah satu strategi pengembangan guru adalah implementasi prinsip pemberdayaan (empowerment) dalam pengembangan guru sekolah dasar. Pemberdayaan (empowerment) merupakan bentuk motivasi intinsik, karena melaksanakan tugas merupakan penghargaan dan memberikan kepuasan intrinsik dalam bentuk kesenangan, kedayatarikan dalam bekerja, pencapaian, meningkatkan pengetahuan dan keterampilan, pengungkapan diri, menghindari frustrasi, kebosanan dan kecemasan di tempat kerja (Colquitt, Jason A. Jeffery A. Lepine, 2015). Pemberdayaan berkaitan dengan upaya memperoleh keterampilan, pengetahuan dan kekuasaan yang cukup untuk mempengaruhi kehidupannya dan orang lain yang menjadi perhatiannya (Margayaningsih, 2015).

Berkaitan dengan pemberdayaan ini, George dan Jones dalam (Widodo \& Sriyono, 2020) mengungkapkan pendekatan dalam proses pemberdayaan, yaitu: (1) membantu karyawan dalam meraih penguasaan kinerja (memberikan pelatihan yang tepat, pelatihan dan pengalaman yang diarahkan pada hasil sebagai awal kesuksesan); (2) mengizinkan pengontrolan yang lebih banyak (memberikan mereka pertimbangan-pertimbangan pada kinerja pekerjaan, dan kemudian membantu mereka pada hasil yang akuntabel); (3) penyediaan model-model keberhasilan mengijinkan mereka untuk mengobservasi teman sejawat yang sudah membantu kesuksesan dalam pekerjaan); (4) menggunakan dukungan sosial dan persuasi (memberi pujian, dorongan, dan umpan balik yang didesain untuk meningkatkan percaya diri); (5) memberi dukungan emosional (menyediakan pereduksian stress dan kebimbangan melalui definisi kerja yang lebih baik, pembantuan tugas dan penanganan yang jujur). Kelima pendekatan ini merupakan strategi dalam proses pemberdayaan. Pendekatan demikian dapat diaplikasikan pada pemberdayaan guru. Kepala Sekolah memiliki banyak alternatif pendekatan dalam meningkatkan kualitas guru.

Pemberdayaan guru secara konsisten dan berkelanjutan memiliki dampak positif pada peningkatan profesionalitas. Pemberdayaan memiliki dampak positif pada perubahan karakter, peningkatan pengetahuan, dan peningkatan keterampilan. Perubahan yang terjadi akan mendorong profesionalisme guru dalam menjalankan tugas dan kewajiban sehingga berdampak pada peningkatan mutu pendidikan. Jika mutu pendidikan meningkat, maka hal itu akan membangun kepuasan dan kepercayaan masyarakat. Karena itu pelaksanaan program peningkatan profesionalitas guru perlu mengarah pada proses pemberdayaan. Proses pemberdayaan tampak pada upaya mendampingi, mengontrol sampai memiliki pemahaman dan penguasaan, membangun kepercayaan diri, dan memberikan dukungan umpan balik sampai guru mampu meningkatkan kemampuan profesional dalam tugas profesinya. Hal ini selaras dengan hasil penelitian (Forefry et al., 2017) bahwa pemberdayaan guru diarahkan pada peningkatan mutu hasil pembelajaran, karena itu pelaksanaan program pemberdayaan guru lebih kepada proses pemberian bimbingan, pimpinan, pengaturan, pengendalian dan pemberian fasilitas lainnya.

Hasil penelitian sebelumnya menunjukkan bahwa pemberdayaan guru memiliki dampak pada peningkatan kualitas guru. Hasil penelitian (Samsilayurni, 2020) bahwa variabel pemberdayaan guru oleh kepala sekolah berpengaruh signifikan terhadap kinerja guru, hal ini ditunjukkan dengan nilai thitung $>$ ttabel (3.176>1.70113) sehingga ada pengaruh pemberdayaan guru oleh kepala sekolah terhadap kinerja guru. Kemudian penelitian yang dilakukan (Setyawan, 2020) menunjukkan bahwa pemberdayaan berpengaruh positif pada kinerja guru pada sekolah. Lalu hasil penelitian (Khairiyansyah, 2015) menunjukkan bahwa 
model pemberdayaan berpengaruh secara parsial terhadap kinerja sekolah. Hal ini ditunjukkan dari hasil analisis uji $t$, dengan hasil pada variabel model pemberdayaan ( $t$ hitung $>t$ tabel) yaitu $t$ hitung 2,693 $>t$ tabel 2,0301 dan nilai $\mathrm{p}=0,011<0,05$. Ketiga hasil penelitian memberikan gambaran bahwa pemberdayaan guru memiliki dampak pada peningkatan kualitas guru sehingga berdampak pada perbaikan mutu pendidikan.

Di sisi lain, pemberdayaan guru seringkali dirasakan kurang efektif. Berdasarkan studi pendahuluan yang dilakukan peneliti, pemberdayaan guru dirasakan kurang efektif karena kurangnya pengawasan dari pihak sekolah dan yayasan, motivasi guru setelah mengikuti pelatihan semakin menurun, komitmen dalam menjalankan tugas rendah, perencanaan pelatihan kurang baik, rencana tindak lanjut pelatihan tidak ada, dan pendekatan kepala sekolah dalam pemberdayaan guru lebih birokratis dibandingkan personal sehingga menimbulkan gap yang tidak sehat dengan guru. Hasil ini mendukung hasil penelitian (Kusumaningrum et al., 2017) bahwa pemberdayaan guru belum optimal karena rasio jumlah guru-siswa belum proporsional; beberapa guru mengajar di lembaga pendidikan lain; kurangnya kesepahaman cara mendidik siswa sesuai visi dan misi sekolah dan pesantren; dan kurang optimalnya supervisi pengajaran. Kemudian hasil penelitian (Huda et al., 2020) menunjukan bahwa pemberdayaan guru berjalan kurang efektif mulai dari perencanaan, pengorganisasian, pelaksanaan, dan evaluasi, karena kurangnya fasilitas dan anggaran, terbatasnya waktu bimbingan, kepala sekolah dan komite sekolah kurang memahami peran dan tugasnya dalam mendukung program peningkatan profesionalitas guru. Kedua hasil penelitian ini merupakan tantangan yang harus diatasi bahwa pemberdayaan guru di sekolah mengalami berbagai problematika.

Gap yang terjadi antara penelitian yang sebelumnya dengan hasil studi pendahuluan menunjukkan adanya problematika pada pemberdayaan guru di sekolah. Keberhasilan pemberdayaan guru sangat bergantung pada perencanaan pemberdayaan yang dilakukan kepala sekolah. Kepala sekolah memiliki andil besar untuk mengontrol efektifitas pemberdayaan guru melalui pengawasan melalui pembinaan secara pribadi, supervisi akademik maupun pembinaan lain yang relevan dengan pengembangan profesionalisme guru.

Penelitian ini bertujuan untuk menganalisis implementasi prinsip pemberdayaan (empowerment) dalam pengembangan guru profesional di sekolah dasar. Implementasi prinsip pemberdayaan guru dikaji berdasarkan teori proses pendekatan empowerment yang dicetuskan George dan Jones dalam (Widodo \& Sriyono, 2020) meliputi (1) membantu guru dalam meraih penguasaan kinerja melalui pelatihan yang tepat, dan pengalaman; (2) membantu pada hasil yang akuntabel; (3) mengijinkan untuk mengobservasi teman sejawat yang sudah membantu kesuksesan dalam pekerjaan; (4) memberi pujian, dorongan, dan umpan balik yang didesain untuk meningkatkan percaya diri; (5) pemberian tugas dan penanganan yang jujur. Adapun indikator penilaian tingkat keberhasilan pemberdayaan guru yang dilakukan kepala sekolah dapat dilihat pada kemampuan mengelola pembelajaran, kemampuan mengelola kurikulum, kemampuan mengelola kesiswaan, dan kemampuan mengelola kegiatan ekstrakurikuler. Para guru diberikan pemberdayaan untuk menguasai pengelolaan bidang-bidang tersebut. Hasil penelitian ini diharapkan memiliki dampak pada peningkatan kualitas guru melalui Implementasi prinsip (empowerment).

\section{METODE PENELITIAN}

Penelitian ini bertujuan untuk menganalisis implementasi prinsip pemberdayaan (empowerment) dalam pengembangan guru profesional. Subjek penelitian adalah kepala sekolah, guru, koordinator kurikulum, koordinator kesiswaan, koodinator ekstrakurikuler. Objek penelitian adalah kegiatan empowerment kepala sekolah terhadap guru, pembelajaran guru, dan koordinator di bidang kurikulum, kesiswaan, dan ekstrakurikuler. Data dikumpulkan melalui pendekatan mixed method. Penggunaan metode kuantitatif dilengkapi dengan metode kualitatif. Data kuantitatif dilakukan melalui penyebaran kuesioner kepada guru dan koordinator kegiatan sekolah perihal perilaku empowerment kepala sekolah dalam memberdayakan guru dan staf, dan evaluasi ketercapaian item-item pemberdayaan guru. Data kualitatif diperoleh melalui wawancara, observasi dan interview sebagai pelengkap data kuantitatif. Analisa data dilakukan dengan 
explanatory mixed method analysis. Data kuantitatif sederhana dianalisa secara deskriptif dan dilanjutkan eksplanasi dan elaborasi.

\section{HASIL DAN PEMBAHASAN PENELITIAN}

Pemberdayaan berkaitan dengan pada rasa tanggung jawab yang membangun kemandirian. Hal ini selaras dengan pendapat (Blanchard, K.H., Carlos, J.P., Randolph, 1995) yang mengungkapkan bahwa pemberdayaan tidak hanya berkaitan dengan pemberian kebebasan untuk bertindak, tetapi juga memiliki tingkat tanggung jawab dan akuntabilitas yang lebih tinggi. Ini menunjukkan bahwa manajemen dalam organisasi harus memberdayakan bawahan sehingga termotivasi, berkomitmen, puas dan membantu organisasi dalam mencapai tujuannya (P. Jaya Kumar \& Ananda Kumar, 2017). Dalam rangka mewujudkan pemberdayaan guru, kepala sekolah terlebih dahulu harus memiliki ciri perilaku sebagai seorang pemimpin yang "memberdayakan". Ciri perilaku kepala sekolah yang "memberdayakan" tampak pada perilaku mengembangkan pengetahuan, keterampilan dan pengalaman melalui pelatihan; membantu pada hasil yang akuntabel (kewajiban menjalankan tanggungjawab secara transparan, dan melaporkan setiap keputusan demi mendapatkan hasil yang maksimal); mendorong guru melakukan observasi terhadap teman sejawat (supervisi teman sejawat); memberi penghargaan (pujian, dorongan, dan umpan balik yang didesain untuk meningkatkan rasa percaya diri); dan delegasi tugas. Kelima hal ini menjadi indikator keberhasilan kepala sekolah dalam proses pemberdayaan guru. Berikut ini merupakan hasil respon para guru terhadap perilaku empowerment kepala sekolah.

\section{Tabel 1}

\section{Evaluasi Empowerment Kepala Sekolah}

\begin{tabular}{|c|c|c|c|}
\hline No & Indikator Penilaian Empowerment Kepala Sekolah & $(\%)$ & Kategori \\
\hline 1 & $\begin{array}{l}\text { Kepala sekolah membantu guru untuk mengembangkan } \\
\text { pengetahuan, keterampilan, dan pengalaman melalui pelatihan; }\end{array}$ & $90 \%$ & Sangat Baik \\
\hline 2 & $\begin{array}{l}\text { Kepala sekolah membantu pada hasil yang akuntabel (kewajiban } \\
\text { menjalankan tanggungjawab secara transparan, dan melaporkan } \\
\text { setiap keputusan demi mendapatkan hasil yang maksimal); }\end{array}$ & $87 \%$ & Sangat Baik \\
\hline 3 & $\begin{array}{l}\text { Kepala sekolah mendorong guru melakukan observasi terhadap } \\
\text { teman sejawat (supervisi teman sejawat) }\end{array}$ & $92 \%$ & Sangat Baik \\
\hline 4 & $\begin{array}{l}\text { Kepala sekolah memberi penghargaan (pujian, dorongan, dan } \\
\text { umpan balik yang didesain untuk meningkatkan rasa percaya diri); }\end{array}$ & $69 \%$ & Cukup \\
\hline \multirow[t]{2}{*}{5} & Kepala sekolah memberikan delegasi tugas (pemberian tugas). & $79 \%$ & Baik \\
\hline & Rata-Rata & $83 \%$ & Baik \\
\hline
\end{tabular}

Kriteria: 86 - 100 : Sangat Baik, 70 - 85 : Baik, 55 - 69 : Cukup, 40 - 54 : Kurang, -39 : Sangat Kurang Sumber: Data Primer Diolah (2020)

Data pada table tersebut menunjukkan bahwa Implementasi prinsip empowerment memberdayakan guru melalui pelatihan, membantu pada hasil yang akuntabel, observasi rekan sejawat, dan delegasi tugas mendapatkan penilaian dengan kategori sangat baik; Sementara perilaku memberikan penghargaan berupa pujian, dorongan, dan umpan balik mendapatkan tingkat penilaian dengan kategori cukup.

Hasil implementasi prinsip empowerment kepala sekolah dalam mengembangkan pengetahuan, keterampilan dan pengalaman melalui pelatihan mendapatkan penilaian dengan kategori sangat baik. Hasil ini menunjukkan adanya perhatian serius kepala sekolah pada pemberdayaan guru melalui pelatihan. Hal ini selaras dengan hasil wawancara dengan kepala sekolah bahwa pemberdayaan guru dilakukan melalui pelatihan, workshop, seminar, dan kegiatan Musyawarah Guru Mata Pelajaran. Pelatihan merupakan investasi masa depan bagi pengembangan kualitas guru dan mutu pendidikan. Hasil penelitian (Mulyawan, 2012) bahwa pengalaman dalam pelatihan menjadi faktor yang paling besar mempengaruhi profesionalisme guru melalui pelatihan pengembangan kurikulum, pelaksanaan MGMP (Musyawarah Guru Mata Pelajaran), 
pelatihan penyusunan admninitrasi pembelajaran seperti silabus, RPP dan kurikulum mempengaruhi tingkat pengetahuan, sikap, dan keterampilan, serta kompetensi profesional guru. Kemudian penelitian (Zeke et al., 2021) mengungkapkan bahwa pelatihan memberi pengaruh pada peningkatan kinerja guru melalui peningkatan kompetensi sikap, pengetahuan, dan keterampilan guru secara berkesinambungan. Namun berdasarkan penuturan kepala sekolah, salah satu tantangan pemberdayaan guru pasca pelatihan adalah menjaga motivasi dan komitmen dalam menjalankan profesi sebagai guru melalui Implementasi materi pelatihan.

Penilaian pada aspek kepala sekolah membantu pada hasil yang akuntabel (kewajiban menjalankan tanggungjawab secara transparan, melaporkan setiap keputusan demi mendapatkan hasil yang maksimal) mendapatkan penilaian dengan kategori sangat baik. Dalam hal ini, kepala sekolah memberdayakan guru agar menjalankan tugas pengajaran sebaik-baiknya, mensharingkan setiap tantangan yang dihadapi untuk kemudian dicarikan solusi, dan memberikan mentoring berkelanjutan. Hal ini menunjukkan keberhasilan pendampingan kepemimpinan kepala sekolah secara informal terhadap guru. Hasil ini mendukung hasil penelitian (Keizer \& Pringgabayu, 2017) bahwa kepemimpinan kepala sekolah secara parsial berpengaruh terhadap kinerja guru.

Penilaian pada aspek mendorong guru melakukan observasi terhadap teman sejawat mendapatkan penilaian dengan kategori sangat baik. Kegiatan ini dilakukan melalui program supervisi teman sejawat. Temuan ini menunjukkan keberhasilan supervisi teman sejawat. Hal ini memiliki kesamaan dengan penelitian (Sahlan, 2018) bahwa pelaksanaan kegiatan supervisi teman sejawat berjalan efektif dalam meningkatkan kinerja guru. Peneliti berkesimpulan bahwa supervisi teman sejawat memiliki dampak pada pengembangan profesionalitas guru. Program ini mendorong sharing pengetahuan dan keterampilan pada teman sejawat. Sebaliknya guru yang disupervisi mendapatkan umpan balik agar lebih baik dalam pembelajaran. Komunikasi yang terjadi lebih bersifat kekeluargaan dan saling membangun.

Penilaian pada aspek memberikan penghargaan (pujian, dorongan, dan umpan balik yang mendorong rasa percaya diri) mendapatkan penilaiaan dengan kategori cukup. Temuan ini menunjukkan bahwa aspek ini perlu mendapatkan perhatian kepala sekolah. Ini adalah pendekatan personal pemimpin pada bawahan. Pujian, dorongan dan umpan balik merupakan penghargaan yang membangkitkan motivasi meningkatkan prestasi kinerja. Hasil penelitian (Nurpina, 2016) menemukan bahwa penghargaan berpengaruh positif pada motivasi prestasi guru. Kemudian (Romli, 2019) mengungkapkan bahwa variabel penghargaan (X) mempunyai pengaruh yang positif atas peningkatan kinerja pendidik dan tenaga kependidikan (Y). Maka dari itu, bila penghargaan mengalami peningkatan yang besarnya satu satuan, maka peningkatan kinerja pendidik dan tenaga kependidikan akan meningkat sebesar 0.534. Temuan penelitian ini dan kedua penelitian sebelumnya mencerminkan pentingnya penghargaan berupa pujian, dorongan dan umpan balik bagi guru. Penghargaan mampu meningkatkan semangat guru menjalankan tugas profesinya.

Adapun penilaian pada aspek delegasi tugas kepada guru mendapatkan penilaian dengan kategori baik. Aspek delegasi tugas adalah pemberian tanggungjawab kepada guru sebagai koordinator pada bidang kurikulum, kesiswaan, dan kegiatan ekstrakurikuler. Delegasi tugas bertujuan untuk membangun kemandirian, kaderisasi, kepercayaan diri, dan rasa tanggungjawab. Hal ini selaras dengan temuan (Samsu, 2015) bahwa delegasi tugas kepala sekolah pada guru memiliki kolerasi positif dengan peningkatan prestasi guru dalam bentuk produktivitas kerja, kualitas kerja, inisiatif kerja, tim kerja dan penyelesaian masalah.

Implementasi prinsip-prinsip empowerment dalam meningkatkan kinerja guru membutuhkan komitmen, konsistensi dan pendekatan khusus kepemimpinan sekolah. Komitmen dan konsistensi dibutuhkan agar kepala sekolah melakukan pemberdayaan disertai pengawasan secara berkelanjutan. Pendekatan khusus perlu agar guru mau bekerja sama dan menyadari tugas dan tanggungjawabnya sebagai pendidik profesional. 


\section{KESIMPULAN}

Berdasarkan hasil penelitian yang telah diuraikan, maka kesimpulan yang dapat diambil dari penelitian ini adalah bahwa kemampuan kepala sekolah dalam melakukan pemberdayaan guru melalui program pelatihan pengetahuan dan keterampilan, mendorong sikap rasa tanggung jawab, pembelajaran melalui program supervisi teman sejawat, dan delegasi tugas yang menimbulkan rasa percaya diri mendapatkan tingkat penilaian dengan kategori sangat baik. Adapun penilaian pada kepala sekolah dalam memberikan penghargaan berupa pujian, dorongan, dan umpan balik mendapatkan penilaian dengan kategori cukup. Secara keseluruhan Implementasi prinsip empowerment kepala sekolah mendapatkan tingkat penilaian dengan kategori baik.

\section{UCAPAN TERIMAKASIH}

Ucapan terima kasih saya sampaikan kepada kepala sekolah, guru dan staf atas kesediaan meluangkan waktu mengisi kuesioner dan bersedia mengikuti kegiatan wawancara peneliti. Semoga hasil penelitian ini dapat bermanfaat bagi sekolah.

\section{DAFTAR PUSTAKA}

Blanchard, K.H., Carlos, J.P., Randolph, W. A. (1995). The Empowerment Barometer and Action Plan. In Blanchard Training and Development.

Colquitt, Jason A. Jeffery A. Lepine, and M. J. W. (2015). Organizational Behavior Improving Performance and Commitment in the Workplace 4 Edition. In New York: McGraw Hill.

Forefry, N., Pembina, D., Pendidikan, G., Sekolah, K., \& Bermutu, S. (2017). Strategi Pemberdayaan Guru oleh Sekolah (Studi Kasus di SMAN 5 dan SMADarul Hikam Kota Bandung). Jurnal Administrasi Pendidikan, 24(1), 47-59. https://doi.org/10.17509/jap.v24i1.6510

Huda, S., Rusmini, R., \& Siregar, N. (2020). Problematika Pemberdayaan Guru Bimbingan Konseling Di Sekolah. JBKI (Jurnal Bimbingan Konseling Indonesia), 5(2), 42. https://doi.org/10.26737/jbki.v5i2.1672

Keizer, H. De, \& Pringgabayu, D. (2017). Pengaruh Kepemimpinan Kepala Sekolah , Motivasi , Dan ICB Cinta Niaga Kota Bandung. Jurnal Manajemen Bisnis Dan Inovasi, 4(1), 14-24.

Khairiyansyah, B. S. (2015). Pengaruh Model Pemberdayaan dan Disiplin Kerja Guru Terhadap Kinerja Sekolah di SMA Negeri 1 Mendo Barat Kabupaten Bangka. Holistic Journal of Management Research, 3(2), 77-93.

Kusumaningrum, D. E., Sumarsono, R. B., \& Gunawan, I. (2017). Problematika Pemberdayaan dan Pengembangan Sumber Daya Manusia di Sekolah Menengah Pertama Berbasis Pesantren. Ilmu Pendidikan: Jurnal Kajian Teori Dan Praktik Kependidikan, 2(2), 139-150. https://doi.org/10.17977/um027v2i22017p139

Margayaningsih, D. I. (2015). Peningkatan Pemberdayaan dan Kemandirian Desa dalam Rangka Otonomi Daerah. Jurnal Publiciana, 8(1), 164-191.

Mulyawan, B. (2012). Issn 1412 - 8683 45. Jurnal Undiksha, 11, 45-65. https://ejournal.undiksha.ac.id/index.php/MKFIS/article/view/453

Nurpina, S. (2016). Pengaruh Penghargaan (Reward) Dan Motivasi Berprestasi Terhadap Prestasi Kerja Guru SMA Negeri Di Kabupaten Sukabumi. Jurnal Manajemen Pendidikan, 7(2), 1337. https://doi.org/10.21009/jmp.07205

P. Jaya Kumar \& Ananda Kumar. (2017). Global Journal of Management and Business Research: A Administration and Management. Employee Empowerment - An Empirical Study, 17(4).

Ramaliya. (2018). Pengembangan Kompetensi Guru Dalam Pembelajaran. Bidayah:Studi Ilmu-Ilmu Keislaman, 9(1), 77-88. 
3727 Analisis Implementasi Prinsip Empowerment Pada Kepemimpinan Kepala Sekolah - Marinu Waruwu DOI: https://doi.org/10.31004/edukatif.v3i6.1232

Romli, O. (2019). Pengaruh Pemberian Penghargaan Terhadap Kinerja Pada Pendidik dan Tenaga Kependidikan Yayasan Khairul Huda Kota Serang Banten. Equilibrium, 8(2), $27-31$.

Sahlan, S. (2018). Pelaksanaan Pembelajaran Melalui Supervisi. Journal Ilmiah Rinjani_Universitas Gunung Rinjan, 7(1), 1-11.

Samsilayurni. (2020). Pengaruh Pemberdayaan Guru oleh Kepala Sekolah Terhadap Kinerja Guru. Innovative Education Journal, 1(1), 1-13.

Samsu, S. (2015). Pengaruh Delegasi, Reward Dan Motivasi Kepala Sekolah Terhadap Prestasi Kerja Guru (Studi Pada Sd/mi, Sltp, Dan Slta Kota Jambi). Al-Fikrah: Jurnal Kependidikan Islam IAIN Sulthan Thaha Saifuddin, 6(October), 56581.

Setyawan, S. (2020). Analisis Pengaruh Pemberdayaan dan Motivasi terhadap Kinerja Guru di Lingungan Yayasan Catur Praya Tunggal Semarang. Majalah Ilmiah Gema Maritim, 22(1), 10-16. https://doi.org/10.37612/gema-maritim.v22i1.44

Widodo, W., \& Sriyono, H. (2020). Strategi pemberdayaan guru dalam meningkatkan mutu pendidikan. Faktor Jurnal Ilmiah Kependidikan, 7(1), 7-12.

Zeke, K., Katuuk, D. A., Lengkong, J. S. J., Nicodemus, V., \& Rotty, J. (2021). Pengaruh Pendidikan dan Pelatihan terhadap Kinerja Guru SMP Kecamatan Somba Opu Kabupaten Gowa. 10, 15-21. 